\title{
MicroRNA-26a/b directly regulate La-related protein 1 and inhibit cancer cell invasion in prostate cancer
}

\author{
MAYUKO KATO $^{1,2}$, YUSUKE GOTO ${ }^{1,2}$, RYOSUKE MATSUSHITA ${ }^{3}$, AKIRA KUROZUMI ${ }^{1,2}$, \\ ICHIRO FUKUMOTO ${ }^{1}$, RIKA NISHIKAWA ${ }^{1,2}$, SHINICHI SAKAMOTO ${ }^{2}$, HIDEKI ENOKIDA ${ }^{3}$, \\ MASAYUKI NAKAGAWA ${ }^{3}$, TOMOHIKO ICHIKAWA ${ }^{2}$ and NAOHIKO SEKI ${ }^{1}$ \\ Departments of ${ }^{1}$ Functional Genomics, ${ }^{2}$ Urology, Chiba University Graduate School of Medicine, Chiba; \\ ${ }^{3}$ Department of Urology, Graduate School of Medical and Dental Sciences, Kagoshima University, Kagoshima, Japan
}

Received April 27, 2015; Accepted May 25, 2015

DOI: $10.3892 /$ ijo.2015.3043

\begin{abstract}
Our past studies of microRNA (miRNA) expression signatures of cancers including prostate cancer $(\mathrm{PCa})$ revealed that microRNA-26a and microRNA-26b (miR-26a and $m i R-26 b)$ were significantly downregulated in cancer tissues. In the present study, we found that restoration of $m i R-26 a$ or $m i R-26 \mathrm{~b}$ significantly inhibited PCa cell invasion. Gene expression data and in silico analysis showed that the gene encoding La-related protein 1 (LARP1) was a putative candidate of $m i R-26 a$ and $m i R-26 b$ regulation. Moreover, luciferase reporter assays revealed that $L A R P 1$ was a direct target of both $m i R-26 a$ and $m i R-26 b$. Overexpression of LARP1 was observed in PCa clinical specimens and knockdown of LARPI inhibited cancer cell migration. Therefore, LARPI acted as an oncogene in PCa cells. Moreover, 'ribosome', 'RNA transport' and 'mTOR signaling pathway' were identified as LARPIregulated pathways. Our present data suggested that loss of tumor-suppressive $m i R-26 a$ and $m i R-26 b$ enhanced cancer cell invasion in $\mathrm{PCa}$ through direct regulation of oncogenic $L A R P 1$. Elucidation of the molecular networks regulated by tumor-suppressive miRNAs will provide insights into the molecular mechanisms of PCa oncogenesis and metastasis.
\end{abstract}

\section{Introduction}

Prostate cancer (PCa) is the most common cause of cancer in men, accounting for about one-quarter of all cases in adult males, and the second leading cause of cancer-related deaths among men in developed countries (1). Multiple treatment options are available for localized PCa with a 5-year survival rate of almost $100 \%$. In contrast, advanced PCa is difficult to

Correspondence to: Dr Naohiko Seki, Department of Functional Genomics, Chiba University Graduate School of Medicine, 1-8-1 Inohana Chuo-ku, Chiba 260-8670, Japan

E-mail: naoseki@faculty.chiba-u.jp

Key words: $m i R-26 a, m i R-26 b, L A R P 1$, prostate cancer, microRNA, tumor suppressor cure. Metastatic PCa is initially treated by androgen-deprivation therapy (ADT); however, it gradually becomes resistant to first-line ADT and progresses to castration-resistant $\mathrm{PCa}$ (CRPC) (2,3). Therefore, it is important to develop a deeper understanding of the molecular mechanisms underlying $\mathrm{PCa}$ metastasis through the use of novel approaches.

The discovery of non-coding RNAs (ncRNAs) in the human genome was an important conceptual breakthrough in the study of cancer (4). Further improvements in our understanding of ncRNAs are necessary to enhance our understanding of the mechanisms of cancer initiation, development and metastasis. In that regard, microRNAs (miRNAs) are small endogenous ncRNA molecules (19-22 bases in length) that regulate protein-coding gene expression by repressing mRNA translation or cleaving RNA transcripts in a sequencespecific manner (5). A substantial amount of evidence suggests that miRNAs are aberrantly expressed in many human cancers and play significant roles in human oncogenesis and metastasis (6-9).

Analyses of miRNA expression signatures in PCa have revealed that several miRNAs that normally acted as tumorsuppressors were downregulated in cancer tissues (10-15). It is believed that normal regulatory mechanisms can be disrupted by the aberrant expression of tumor-suppressive or oncogenic miRNAs in cancer cells. Therefore, identification of aberrantly expressed miRNAs is an important first step toward elucidating the details of miRNA-mediated oncogenic pathways. Recent study of several miRNA signatures of PCa showed that the expression of $m i R-26 a$ and $m i R-26 b$ was frequently reduced in cancer tissues compared with normal prostate tissues (16), suggesting that $m i R-26 a$ and $m i R-26 b$ act as tumor suppressors in $\mathrm{PCa}$.

The aim of the present study was to investigate the functional significance of $m i R-26 a$ and $m i R-26 b$. This investigation included identifying their molecular targets and the downstream genes modulated in PCa cells. Our data demonstrated that restoration of mature miR-26a and $m i R-26 b$ inhibited cancer cell invasion. Moreover, gene expression data and in silico database analysis showed that the gene coding for La-related protein 1 ( $L A R P 1)$, an RNA-binding protein, was a direct regulatory target of both $m i R-26 a$ and $m i R-26 b$. Silencing of LARPI significantly inhibited cancer cell inva- 
Table I. The patient characteristics.

\begin{tabular}{rrrrrrrr}
\hline No. & $\begin{array}{c}\text { Age } \\
\text { (years) }\end{array}$ & $\begin{array}{c}\text { PSA } \\
\text { (ng/ml) }\end{array}$ & $\begin{array}{c}\text { Gleason } \\
\text { score }\end{array}$ & Stage & cT & cN & cM \\
\hline 1 & 64 & 5.43 & $3+4$ & III & $3 \mathrm{a}$ & 0 & 0 \\
2 & 68 & 12.81 & $3+5$ & III & $3 \mathrm{a}$ & 0 & 0 \\
3 & 70 & 16.06 & $4+5$ & III & $3 \mathrm{~b}$ & 0 & 0 \\
4 & 69 & 25.79 & $4+5$ & II & $2 \mathrm{a}$ & 0 & 0 \\
5 & 64 & 29.93 & $4+3$ & II & $2 \mathrm{~b}$ & 0 & 0 \\
6 & 61 & 7.85 & $3+4$ & III & $3 \mathrm{a}$ & 0 & 0 \\
7 & 68 & 8.78 & $4+5$ & II & $2 \mathrm{~b}$ & 0 & 0 \\
8 & 66 & 6.13 & $4+3$ & II & $2 \mathrm{~b}$ & 0 & 0 \\
9 & 70 & 11.75 & $4+4$ & III & $3 \mathrm{~b}$ & 0 & 0 \\
10 & 60 & 22.1 & $3+4$ & II & $2 \mathrm{~b}$ & 0 & 0 \\
11 & 70 & 8.88 & $3+4$ & II & $2 \mathrm{a}$ & 0 & 0 \\
12 & 72 & 4.48 & $3+4$ & II & $2 \mathrm{~b}$ & 0 & 0 \\
13 & 56 & 7.12 & $3+4$ & III & $3 \mathrm{a}$ & 0 & 0 \\
14 & 65 & 13.08 & $4+3$ & II & $2 \mathrm{~b}$ & 0 & 0 \\
15 & 65 & 9.53 & $4+4$ & II & $2 \mathrm{~b}$ & 0 & 0 \\
16 & 65 & 5.8 & $4+3$ & II & $2 \mathrm{a}$ & 0 & 0 \\
17 & 65 & 4.59 & $5+4$ & II & $2 \mathrm{~b}$ & 0 & 0 \\
\hline
\end{tabular}

sion. Moreover, genome-wide gene expression analysis was performed to investigate downstream pathways of $L A R P I$ using si-LARPl transfectants. By categorizing LARPIregulated genes using KEGG pathways, 'ribosome', 'RNA transport' and 'mTOR signaling pathway' were identified as LARP1-regulated pathways. The discovery of tumor suppressive $m i R$-26a/b-modulated molecular pathways provides new insights into potential mechanisms of PCa oncogenesis and suggests novel therapeutic strategies for the treatment of the disease.

\section{Materials and methods}

Clinical prostate specimens and cell culture. Clinical prostate specimens were obtained from patients with $\mathrm{PCa}$ who underwent radical prostatectomy at Chiba University Hospital from 2009 to 2013. Seventeen paired samples of PCa and corresponding normal tissues from prostatectomy specimens were used for the present study. Those samples that were considered normal were free of cancer cells as determined by pathological examination. The background of the patients and pathological characteristics are summarized in Table I. The protocol was approved by the Institutional Review Board of Chiba University. All patients provided written informed consent for tissue donation for research purposes before tissue collection.

We used the human PCa cell lines PC3 and PC3M, obtained from the American Type Culture Collection (ATCC; Manassas, VA, USA). PC3 originated from a PCa patient with bone metastasis. PC3M was obtained upon injection of PC3 cells into nude mice and was derived from a liver metastasis following intrasplenic injection of PC3. PC3 and PC3M cells were maintained in RPMI-1640 medium supplemented with $10 \%$ fetal bovine serum (FBS) in a humidified atmosphere of $5 \% \mathrm{CO}_{2}$ and $95 \%$ air at $37^{\circ} \mathrm{C}$.

RNA isolation. Total RNA was isolated using TRIzol reagent (Invitrogen, Carlsbad, CA, USA) according to the manufacturer's protocol. The quality of RNA was confirmed using an Agilent 2100 Bioanalyzer (Agilent Technologies, Santa Clara, CA, USA).

Quantitative real-time RT-PCR. The procedure for PCR quantification was conducted as previously described $(10,12,15)$. The expression of $m i R-26 a$ (assay ID: 000405; Applied Biosystems, Foster City, CA, USA) and miR-26b (assay ID: 000407; Applied Biosystems) was analyzed by TaqMan quantitative real-time PCR and normalized to the expression of RNU48 (assay ID: 001006; Applied Biosystems). TaqMan probes and primers for LARP1 (P/N: Hs00391726_m1; Applied Biosystems), GUSB (the internal control; $\mathrm{P} / \mathrm{N}$ : Hs00939627_m1; Applied Biosystems) and GAPDH (the internal control; P/N: Hs02758991_g1; Applied Biosystems) were assay-on-demand gene expression products.

Transfection with mature miRNA and small interfering RNA (siRNA). The following mature miRNA species were used in the present study: Ambion Pre-miR miRNA precursor for hsa-miR-26a-5p (product ID: PM10249; Applied Biosystems) and Ambion Pre-miR miRNA precursor for $h s a-m i R-26 b-5 p$ (product ID: PM12899; Applied Biosystems). The following siRNAs were used: Stealth Select RNAi siRNAs; si-LARPI (cat no. HSS118648, HSS118649; Invitrogen) and negative control miRNA/siRNA (P/N: AM17111; Applied Biosystems). RNAs were incubated with OPTI-MEM (Invitrogen) and Lipofectamine RNAiMax reagent (Invitrogen) as previously described $(10,12,15)$.

Cell proliferation and invasion assays. Cells were transfected with $10 \mathrm{~nm}$ miRNA or siRNA by reverse transfection and plated in 96-well plates at $3 \times 10^{3}$ cells/well. After $72 \mathrm{~h}$, cell proliferation was determined with the XTT assay using a Cell Proliferation kit II (Roche Applied Sciences, Tokyo, Japan), as previously reported $(10,12,15)$.

A cell invasion assay was carried out using modified Boyden chambers containing Transwell-precoated Matrigel membrane filter inserts with $8-\mu \mathrm{m}$ pores in 24 -well tissue culture plates, with cells plated at $1 \times 10^{5}$ cells/well (BD Biosciences) as previously reported $(10,12,15)$. All experiments were performed in triplicate.

Genome-wide gene expression and in silico analysis for the identification of genes regulated by miR-26a and miR-26b. To identify $m i R-26 a$ and $m i R-26 b$ target genes, we used a combination of in silico and genome-wide gene expression analyses. First, we screened genes using TargetScan Release 6.2 (http://www.targetscan.org/). Next, to identify upregulated genes in clinical PCa specimens, we analyzed a publicly available gene expression data set in the GEO database (accession number: GSE29079). We merged these data sets and selected putative $m i R-26 a$ and $m i R-26 b$ target genes in the present study. 
A

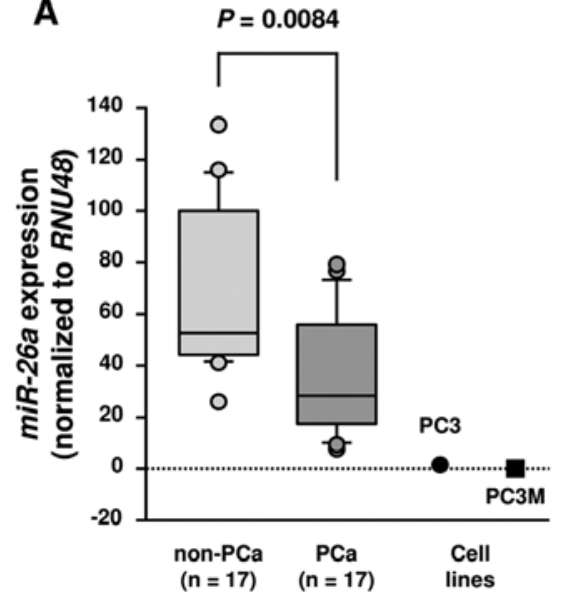

B

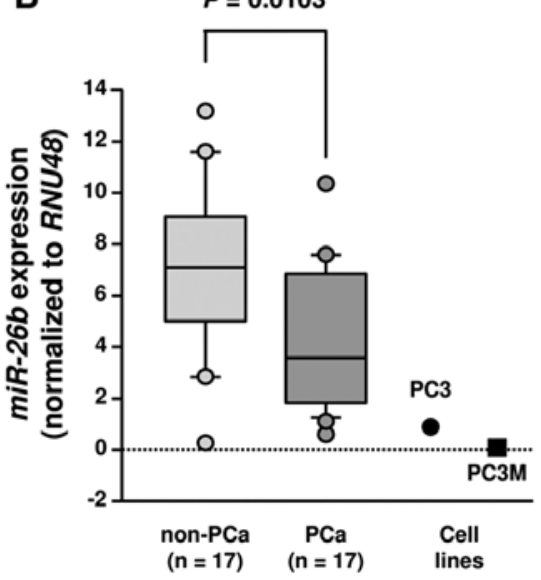

C
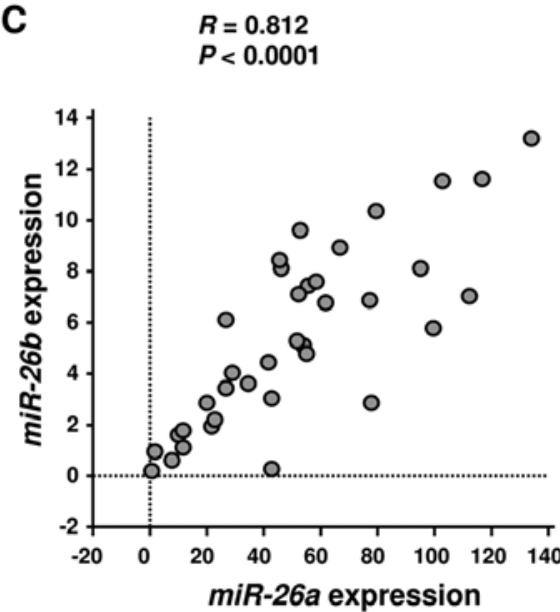

Figure 1. Expression levels of $m i R-26 a$ and $m i R-26 b$ in prostate specimens. Expression levels of (A) $m i R-26 a$ (A) and (B) $m i R-26 b$ in clinical prostate specimens and cell lines, PC3 and PC3M. RNU48 was used for normalization. (C) Correlation among the relative expression levels of $m i R-26 a$ and $m i R$-26b.

Identification of downstream pathways and genes regulated by LARP1. To identify molecular pathways regulated by $L A R P 1$ gene expression in cancer cells, we performed gene expression analysis using si-LARPI-transfected PC3 cells. An oligomicroarray (human $60 \mathrm{Kv}$; Agilent Technologies) was used for gene expression studies. Gene expression data were categorized according to the Kyoto Encyclopaedia of Genes and Genomes (KEGG) pathways using the GeneCodis program (http://genecodis.dacya.ucm.es). The strategy behind this analysis procedure has been described $(12,14,15,19)$.

Western blotting. Cells were harvested $72 \mathrm{~h}$ after transfection, and lysates were prepared. Cell lysates (20 $\mu \mathrm{g}$ protein) were separated on Mini-PROTEAN TGX gels (Bio-Rad Laboratories, Hercules, CA, USA) and transferred to PVDF membranes. Immunoblotting was performed with rabbit anti-LARP1 antibodies (1:200, SC-102006; Santa Cruz Biotechnology, Inc., Dallas, TX, USA). Anti-GAPDH antibodies (1:1,000, ab8245; Abcam) were used as an internal loading control. Membranes were washed and incubated with anti-rabbit IgG horseradish peroxidase (HRP)-linked antibodies (7074; Cell Signaling Technology, Danvers, MA, USA). Complexes were visualized with Clarity Western ECL Substrate (Bio-Rad Laboratories).

Plasmid construction and dual-luciferase reporter assays. Partial wild-type (WT) sequences of the LARPI 3'-untranslated region (UTR) or those with deleted $m i R-26 a / 26 b$ target sites (positions 2527-2533, 3337-3344 and 3494-3500 of the LARPI 3'-UTR) were inserted between the XhoI-PmeI restriction sites in the 3'-UTR of the hRluc gene in the psiCHECK-2 vector (C8021; Promega, Madison, WI, USA). The synthesized DNA was cloned into the psiCHECK-2 vector. PC3 cells were transfected with $50 \mathrm{ng}$ of the prepared vector and $10 \mathrm{nM}$ $m i R-26 a$ and $m i R-26 b$ using Lipofectamine 2000 (Invitrogen). The activities of firefly and Renilla luciferases in cell lysates were determined with a dual-luciferase assay system (E1910; Promega). Normalized data were calculated as the ratio of Renilla/firefly luciferase activities as previously described $(10,12,15)$.
Immunohistochemistry. A total of 17 radical prostatectomy specimens were used (Table I). Tissue specimens were immunostained with the UltraVision Detection System (Thermo Fisher Scientific, Fremont, CA, USA) following the manufacturer's protocol. Primary rabbit polyclonal antibodies against LARP1 (SC-102006; Santa Cruz Biotechnology) were diluted 1:50. The slides were treated with biotinylated goat antibodies.

Statistical analysis. The relationships between 2 groups and the numerical values obtained by qRT-PCR were analyzed using the Mann-Whitney $U$ test. The relationships among more than 3 variables and numerical values were analyzed using the Bonferroni-adjusted Mann-Whitney U test. All analyses were performed using Expert StatView (version 5; SAS Institute Inc., Cary, NC, USA).

\section{Results}

Expression levels of miR-26a/26b in PCa specimens and cell lines. First, we evaluated the expression of $m i R-26 a$ and $m i R-26 b$ in 17 radical prostatectomy specimens (Table I; nos. 1-17). Patients had a median PSA level of $8.88 \mathrm{ng} / \mathrm{ml}$ (range, $4.48-29.93 \mathrm{ng} / \mathrm{ml}$ ) and $35.3 \%$ of patients were classified as cT3a or cT3b according to the TNM classification. The expression levels of $m i R-26 a$ and $m i R-26 b$ were significantly lower in cancer tissues than in non-cancerous tissues $(\mathrm{P}=0.0084$ and $\mathrm{P}=0.0103$, respectively; Fig. $1 \mathrm{~A}$ and $\mathrm{B}$ ). Additionally, $\mathrm{PC} 3$ and PC3M cells also exhibited low expression of $m i R-26 a$ and $m i R-26 b$ compared to normal prostate tissues (Fig. 1A and B).

Spearman's rank test showed positive correlations between the expression of $m i R-26 a$ and $m i R-26 b(\mathrm{R}=0.812$ and $\mathrm{P}<0.0001$; Fig. 1C).

Effects of miR-26a/26b restoration on the proliferative and invasive properties of $P C 3$ and PC3M cells. To investigate the functional effects of $m i R-26 a$ and $m i R-26 b$, we performed gain-of-function studies using miRNA transfection of PC3 and PC3M cells. XTT assays demonstrated that cell proliferation was not inhibited in $m i R-26 a / 26 b$ transfectants in comparison with mock- or miR-control transfected PC3 cells (Fig. 2A). 
Table II. Candidate of target genes regulated by $m i R-26 a$ and $m i R-26 b$ in $\mathrm{PCa}$.

\begin{tabular}{|c|c|c|c|c|c|c|c|}
\hline $\begin{array}{l}\text { Entrez } \\
\text { gene ID }\end{array}$ & Symbol & Gene name & Location & $\begin{array}{c}\text { Total no. } \\
\text { of target } \\
\text { sites }\end{array}$ & $\begin{array}{l}\text { No. of } \\
\text { conserved } \\
\text { target } \\
\text { sites }\end{array}$ & $\begin{array}{l}\text { No. of } \\
\text { poorly } \\
\text { conserved } \\
\text { target } \\
\text { sites }\end{array}$ & $\begin{array}{l}\text { GEO } \\
\text { fold-change }\end{array}$ \\
\hline 23367 & LARP1 & La ribonucleoprotein domain family, member 1 & $5 q 33.2$ & 3 & 2 & 1 & 1.218770 \\
\hline 9185 & REPS2 & RALBP1 associated Eps domain containing 2 & Xp22.13 & 2 & 1 & 1 & 1.120692 \\
\hline 23600 & $A M A C R$ & $\alpha$-methylacyl-CoA racemase & $5 \mathrm{p} 13.2$ & 1 & 0 & 1 & 2.492311 \\
\hline 2153 & $F 5$ & Coagulation factor $\mathrm{V}$ (proaccelerin, labile factor) & $1 \mathrm{q} 24.2$ & 1 & 0 & 1 & 1.781092 \\
\hline 6424 & SFRP4 & Secreted frizzled-related protein 4 & $7 \mathrm{p} 14.1$ & 1 & 0 & 1 & 1.379926 \\
\hline 23327 & $N E D D 4 L$ & $\begin{array}{l}\text { Neural precursor cell expressed, } \\
\text { developmentally downregulated 4-like }\end{array}$ & $18 \mathrm{q} 21.31$ & 1 & 0 & 1 & 1.241135 \\
\hline 10257 & $A B C C 4$ & $\begin{array}{l}\text { ATP-binding cassette, sub-family C } \\
\text { (CFTR/MRP), member } 4\end{array}$ & $13 q 32.1$ & 1 & 1 & 0 & 1.238627 \\
\hline 1612 & $D A P K 1$ & Death-associated protein kinase 1 & $9 q 21.33$ & 1 & 1 & 0 & 1.116046 \\
\hline 58499 & ZNF462 & Zinc finger protein 462 & $9 \mathrm{q} 31.2$ & 1 & 1 & 0 & 1.026692 \\
\hline 56894 & AGPAT3 & 1-acylglycerol-3-phosphate O-acyltransferase 3 & $21 \mathrm{q} 22.3$ & 1 & 0 & 1 & 1.013560 \\
\hline
\end{tabular}
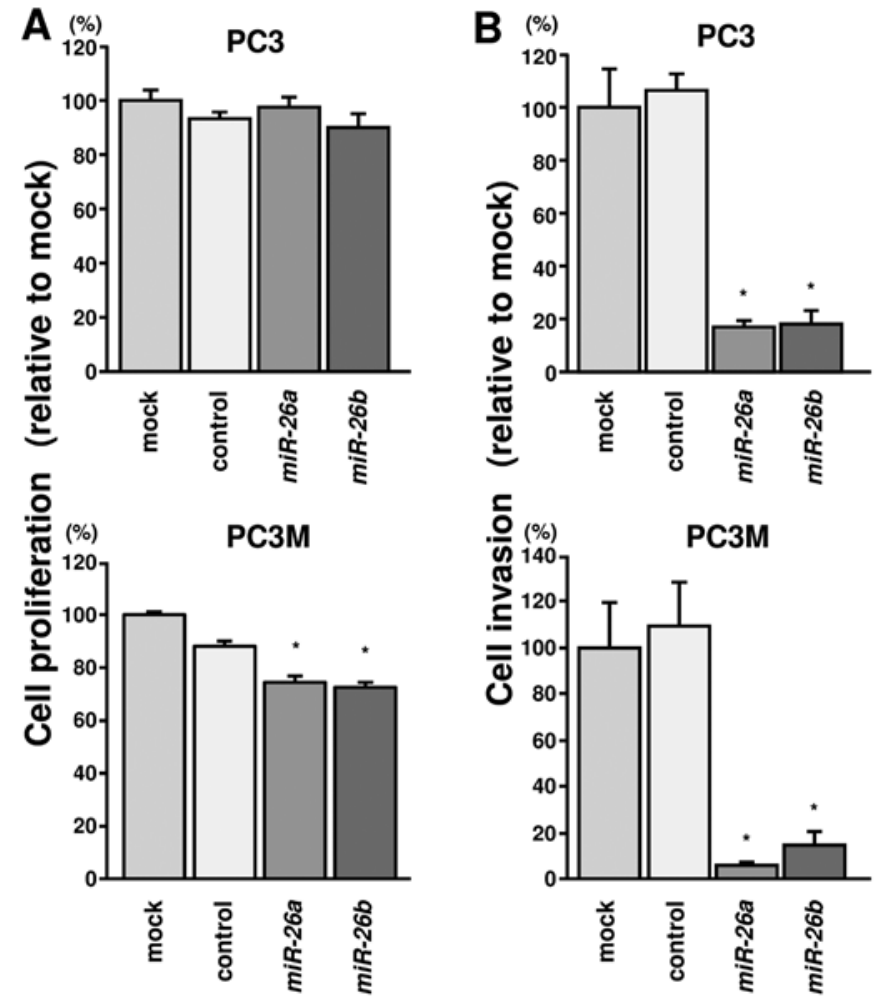

Figure 2. Effects of $m i R-26 a$ and $m i R-26 b$ transfection on cell proliferation and invasion in PC3 and PC3M cells. (A) Cell proliferation was determined $72 \mathrm{~h}$ after transfection with $m i R-26 a$ and $m i R-26 b$ using XTT assays. (B) Effects of $m i R-26 a$ and $m i R-26 b$ transfection on cell invasion in PC3 and PC3M cells. Cell invasion activity was determined $48 \mathrm{~h}$ after transfection with $m i R-26 a$ and $m i R-26 b$ using Matrigel invasion assays. ${ }^{*} \mathrm{P}<0.0001$. Experiments were performed triplicate. Error bars indicate SD.

However, restoration of $m i R-26 a$ and $m i R-26 b$ did inhibit PC3M cell proliferation (Fig. 2A). In cell invasion assays, $m i R-26 a$ and $m i R-26 b$ transfection significantly inhibited cell invasion compared with mock- or miR-control transfectants in both PC3 and PC3M cells (Fig. 2B).

Identification of candidate target genes of $m i R-26 a / 26 b$ in $P C a$ cells. To identify target genes of miR-26a and miR-26b, we performed in silico analysis and gene expression analysis. First, the TargetScan program showed that 2,589 genes had putative target sites for $m i R-26 a$ and $m i R-26 b$ in their 3 '-UTR regions. To gain further insight into which genes were affected by tumor-suppressive $m i R-26 a$ and $m i R-26 b$ in PCa, the genes were analyzed with available gene expression data from GEO (accession no. GSE29079), and we selected genes that were upregulated $\left(\log _{2}\right.$ ratio $\left.>1.0\right)$. Ten candidate genes were identified as targets of $m i R-26 a$ and $m i R-26 b$ (Table II). Of these, we focused on the $L A R P I$ gene for further analyses because it has two putatively conserved target sites and one poorly conserved target site. Moreover, the functional significance of $L A R P I$ in PCa cells had not been determined.

$L A R P 1$ was directly regulated by miR-26a and miR-26b. Next, we performed qRT-PCR and western blotting to confirm that restoration of $m i R-26 a$ and $m i R-26 b$ resulted in downregulation of LARP1 in PC3 and PC3M cells. The mRNA and protein expression levels of LARP1 were significantly repressed in $m i R-26 a$ and $m i R-26 b$ transfectants in comparison with mock or miR-control transfectants $(\mathrm{P}<0.0005$; Fig. 3A and $\mathrm{B})$.

We then performed luciferase reporter assays in PC3 cells to determine whether $L A R P 1 \mathrm{mRNA}$ was directly regulated by $m i R-26 a$ and $m i R-26 b$. The TargetScan database predicted that three putative $m i R-26 a / 26 b$-binding sites existed in the 3'-UTR of LARPI (positions 2527-2533, 3337-3344 and 3494-3500; Fig. 3C). We used vectors encoding either the partial WT sequence of the 3'-UTR of LARPI mRNA, including the predicted $m i R-26 a / 26 b$ target sites, or deletion vectors that lacked the miR-26a/26b target sites. We found that the luminescence intensities were significantly reduced 


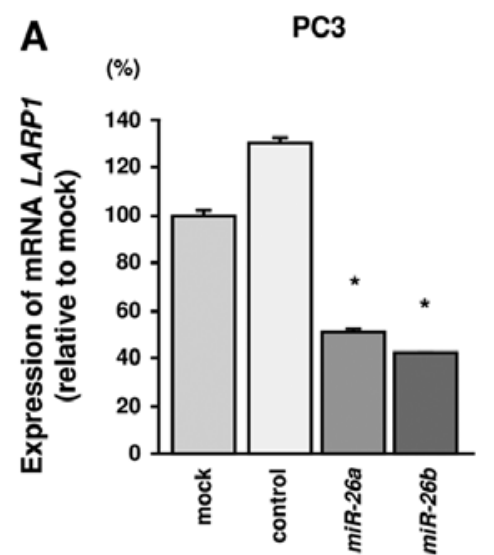

C
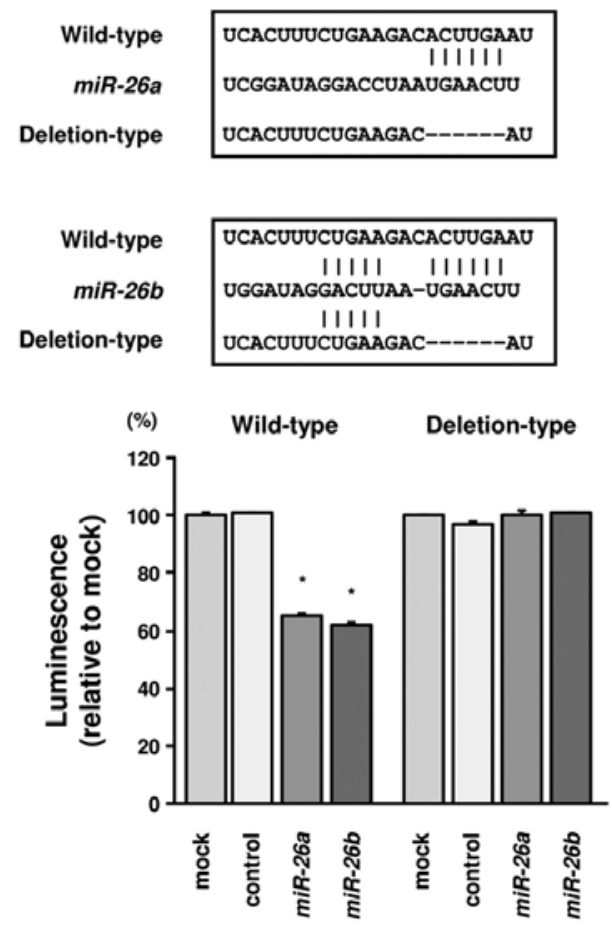

PC3M

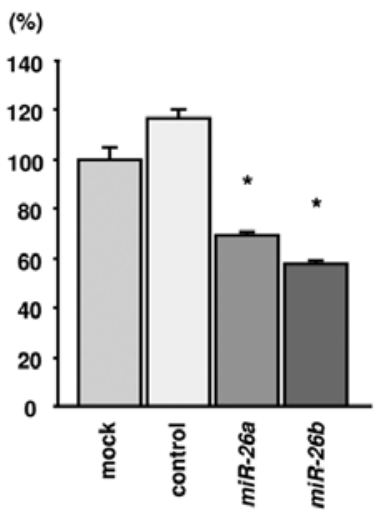

B

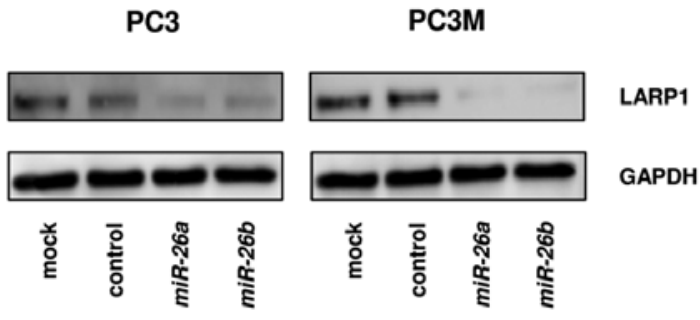

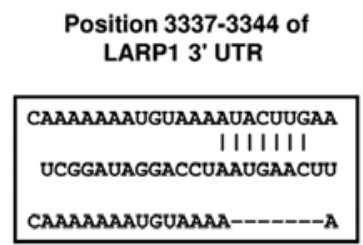
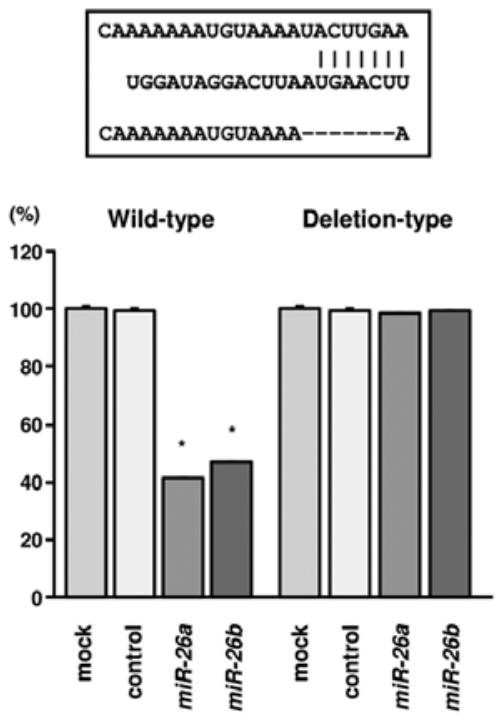

Position 3494-3500 of LARP1 3' UTR

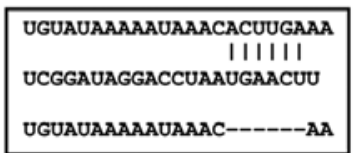

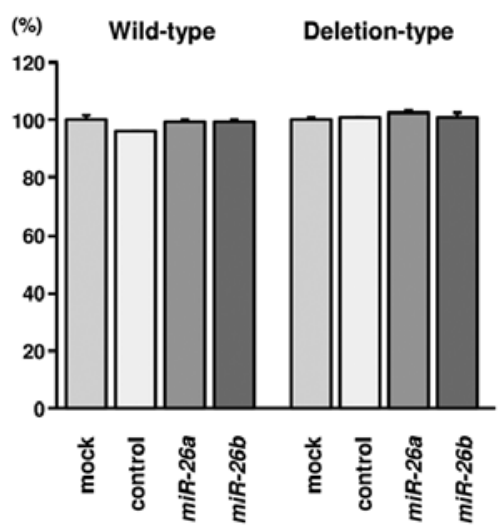

Figure 3. Downregulation of $L A R P 1$ expression by $m i R-26 a$ and $m i R-26 b$ in PC3 and PC3M cells. (A) $L A R P 1$ mRNA expression $72 \mathrm{~h}$ after transfection with $m i R-26 a$ or $m i R-26 b$. GUSB was used as an internal control. ${ }^{*} \mathrm{P}<0.0001$. (B) LARP1 protein expression $72 \mathrm{~h}$ after transfection with $m i R-26 a$ or $m i R-26 b$. GAPDH was used as a loading control. (C) miR-26a and $m i R-26 b$ binding sites in $L A R P 1$ mRNA. Luciferase reporter assays were carried out using a vector encoding the putative $m i R-26 a$ and $m i R$-26b target sites in the LARP1 3'-UTR (positions 2527-2533,3337-3344 and 3494-3500) for WT and deletion constructs. ${ }^{*} \mathrm{P}<0.0001$. Experiments were performed in triplicate. The bars indicate SD.

by transfection with miR-26a/26b and vectors carrying the WT 3'-UTR of LARPI (positions 2527-2533 and 3337-3344), whereas transfection with deletion vectors blocked the decrease in luminescence $(\mathrm{P}<0.0001$; Fig. 3C). These data suggested that $m i R-26 a / 26 b$ bound directly to specific sites in the 3'-UTR of LARPI mRNA.

Effects of silencing LARP1 on cell proliferation and invasion in PCa cell lines. To investigate the functional role of LARPI, we performed loss-of-function studies using si-LARPI transfectants. First, we evaluated the knockdown efficiency of si-LARP1 transfection in PC3 and PC3M cells. qRT-PCR and western blotting indicated that si-LARPI transfection effec- tively downregulated $L A R P 1$ expression in $\mathrm{PC} 3$ and $\mathrm{PC} 3 \mathrm{M}$ cells $(\mathrm{P}<0.0001$; Fig. 4A and $\mathrm{B})$.

In functional assays, cell proliferation was inhibited by transfection with si-LARPI in comparison with mock- or si-control-transfected PC3 and PC3M cells (Fig. 4C). Similarly, Matrigel invasion assays demonstrated that cell invasion was significantly inhibited in si-LARPl transfectants in comparison with mock- or si-control-transfected PC3 and PC3M cells ( $\mathrm{P}<0.0001$; Fig. 4D).

Expression of LARP1 protein in PCa clinical specimens. We validated strong LARP1 expression in radical prostatectomy specimens by immunohistochemical staining. LARP1 was 

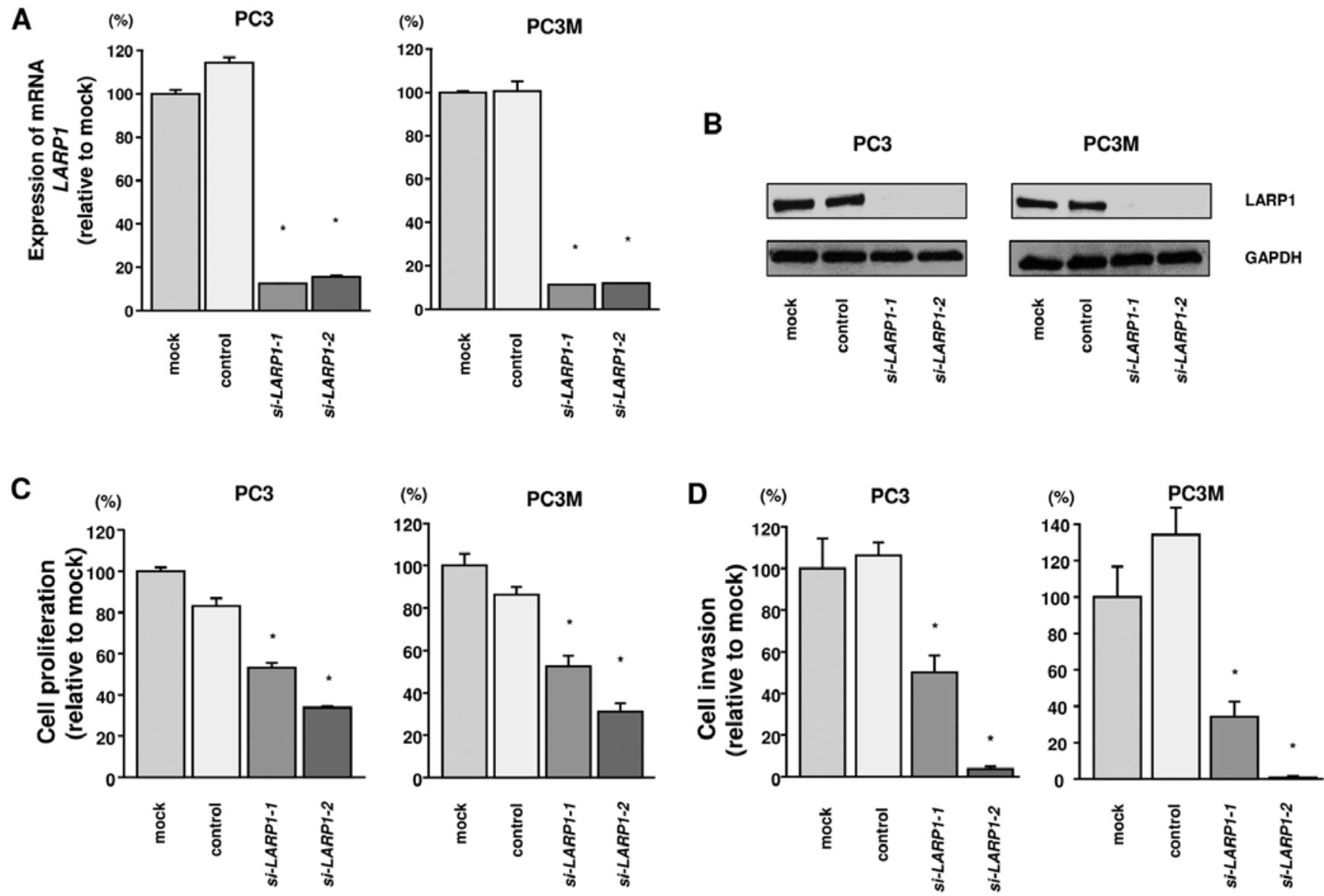

Figure 4. Effects on PCa cell line proliferation and invasion after silencing of LARP1 mRNA and protein expression with si-LARP1 transfection. (A) LARPI mRNA expression was determined $72 \mathrm{~h}$ after transfection with si-LARP1. GUSB was used as an internal control. " $\mathrm{P}<0.0001$. (B) LARP1 protein expression was evaluated by western blotting $48 \mathrm{~h}$ after transfection with si-LARP1. GAPDH was used as a loading control. (C) Cell proliferation was determined by XTT assays. "P $<0.0001$. (D) Cell invasion activity was determined by Matrigel invasion assays. ${ }^{*} \mathrm{P}<0.0001$. Experiments were performed triplicate. The bars indicate SD.

strongly detected in several PCa specimen, whereas no or low expression was observed in non-cancerous lesions (Fig. 5).

Genes downstream of LARPI in PC3 cells. To further investigate the roles of $L A R P 1$ in PC3 cells, we performed genome-wide gene expression analysis using si-LARPI. We categorized 358 genes significantly downregulated by si-LARPI-1 and si-LARP1-2 compared with mock transfectant $\left(\log _{2} \mathrm{FC}<-0.5\right)$ by KEGG pathway analysis. As Table III shows, 17 pathways were significantly downregulated by si-LARP1, the most prominent of which was the ribosome pathway $(\mathrm{P}=7.07 \mathrm{E}-35)$.

\section{Discussion}

A growing body of evidence has shown that miRNAs are involved in several biological processes. Importantly, they are closely associated with human oncogenesis and metastasis (17). In normal cells, miRNA closely regulates RNA molecular networks. In contrast, aberrantly expressed miRNAs can disrupt the otherwise tightly regulated relationship between miRNA and mRNA, leading to growth and metastasis of cancer cells. Therefore, identification of aberrantly expressed miRNAs in cancer cells is the first step in elucidating abnormal molecular signaling networks contributing to oncogenesis.

Based on the miRNA expression signature of $\mathrm{PCa}$, we have identified downregulated miRNAs and proved their tumorsuppressive functions in PCa cells. They include $m i R-1 / 133 a$, $m i R-143 / 145, m i R-23 b / 27 b / 24-1$, the $m i R-29$-family and $\operatorname{miR}-218$ (10-15).

In the present study, we focused on $m i R-26 a$ and $m i R-26 b$ because the expression levels of these miRNAs were reduced in the miRNA signatures of PCa and other types of cancers $(16,18,19)$. In the human genome, the $m i R$-26-family consists of three subtypes of miRNAs: $m i R-26 a-1, m i R-26 a-2$ and $m i R-26 b$. The mature sequences of $m i R-26 a-1$ and $m i R-26 a-2$ are identical, whereas two differ in $m i R-26 b$ (miRBase release 21 ; http://www.mirbase.org/). The seed sequences of these miRNAs are identical, suggesting that miR-26-family regulated genes are identical in human cells. Silencing of protein-coding RNAs and miRNAs results from aberrant DNA methylation and epigenetic modification (20). Aberrant DNA hypermethylation by overexpression of DNMT3b causes the silencing of $m i R-26 a$ and $m i R-26 b$ in breast cancer cell lines (21). Expression of $m i R-26 a$ was increased by treatment with 5-aza-2-deoxycytidine in a prostate cancer cell line (22). Notably, MYC protein directly binds to promoter regions of 

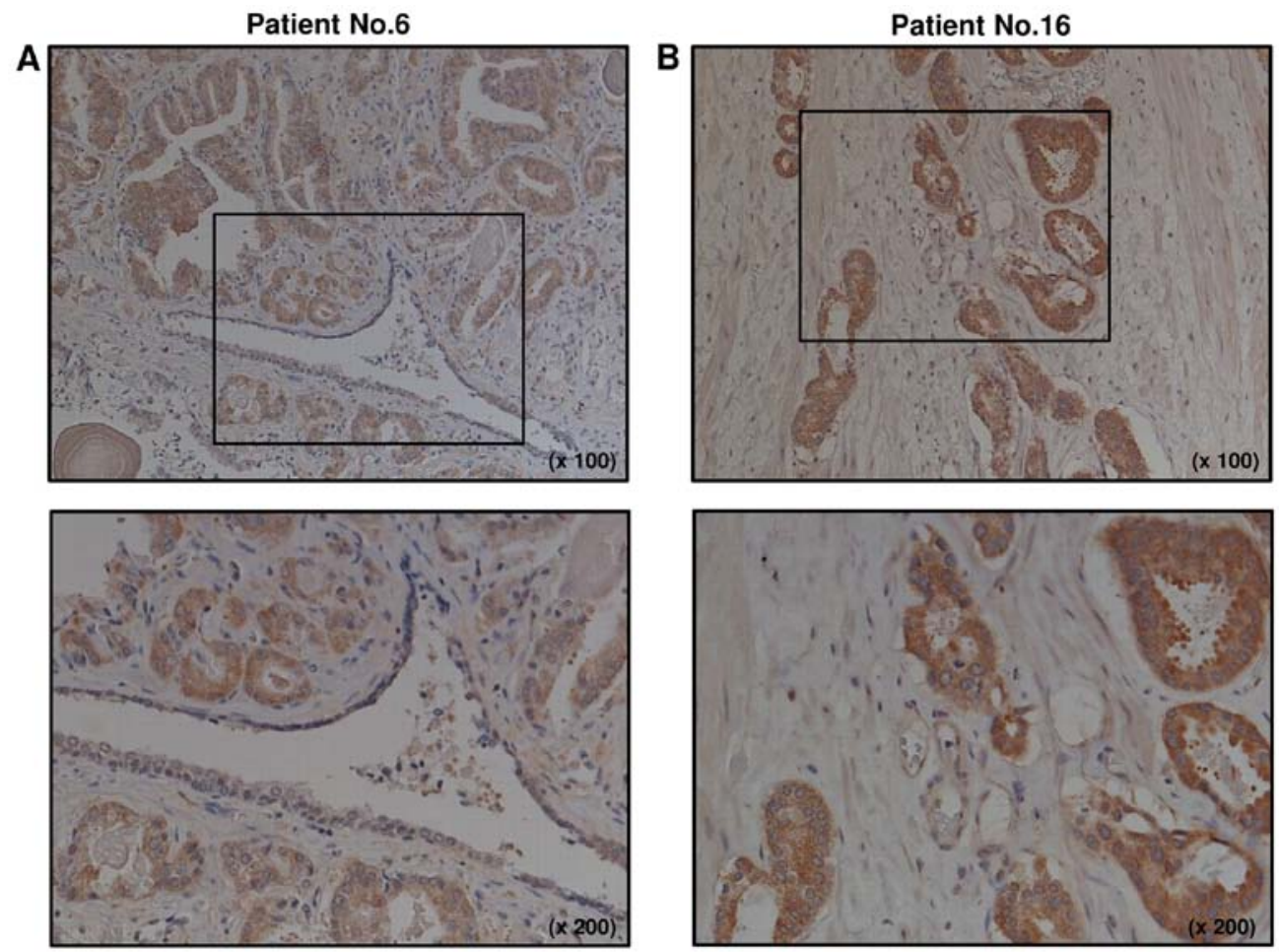

Figure 5. Immunohistochemical staining of LARP1 in prostate clinical specimens. Differences in LARP1 expression were observed in cancer lesions and adjacent normal prostate tissues in the same fields. (A) Patient number 6 and (B) patient number 16. Overexpression of LARP1 was observed in cancer lesions. In contrast, negative staining of LARP1 was seen in normal prostate glands and stromal tissues. (Upper panel, original magnification, x100; lower panel, original magnification, $\mathrm{x} 200$ ).

Table III. Significantly enriched KEGG pathways and involved genes modulated by si-LARP1 in PC3 cells.

\begin{tabular}{|c|c|c|c|c|}
\hline $\begin{array}{l}\text { No. of } \\
\text { genes }\end{array}$ & $\begin{array}{l}\text { KEGG } \\
\text { pathway } \\
\text { number }\end{array}$ & Annotation & P-value & Genes \\
\hline 26 & 3010 & Ribosome & $7.07 \mathrm{E}-35$ & $\begin{array}{l}\text { RPL24, RPL29, RPL10L, RPL15, RPS15A, RPS3A, } \\
\text { RPL4, RPS23, RPS9, RPL17, RPS3, RPS }, \\
\text { RPL23A, RPL5, RPL31, RPL10, RPL22, RPSA, } \\
\text { RPL7, RPL26, RPL39, RPL23, RPS6, RPL21, } \\
\text { RPL9, RPL3 }\end{array}$ \\
\hline 6 & 3030 & DNA replication & $2.24 \mathrm{E}-07$ & RNASEH2A, LIG1, RPA3, POLD1, RFC5, PRIM1 \\
\hline 5 & 3420 & Nucleotide excision repair & $1.36 \mathrm{E}-05$ & ERCC1,LIG1, RPA3, POLD 1, RFC5 \\
\hline 4 & 3430 & Mismatch repair & $2.43 \mathrm{E}-05$ & $L I G 1, R P A 3, P O L D 1, R F C 5$ \\
\hline 7 & 4110 & Cell cycle & 4.11E-05 & $\begin{array}{l}\text { PTTG2, E2F1, CCNB1, BUB1B, CDC45, BUB1, } \\
\text { CDK1 }\end{array}$ \\
\hline 6 & 240 & Pyrimidine metabolism & 7.33E-05 & TYMS , RRM1, POLD1, PRIM1, TK1,DUT \\
\hline 6 & 3013 & RNA transport & 8.09E-04 & EIF3F, EEF1A1, THOC7, EIF4B, POP1, EIF3E \\
\hline 3 & 3440 & Homologous recombination & $9.48 \mathrm{E}-04$ & $R P A 3, P O L D 1, R A D 54 L$ \\
\hline 6 & 230 & Purine metabolism & $1.26 \mathrm{E}-03$ & ENPP1, RRM1, POLD1, IMPDH2, GMPS, PRIM1 \\
\hline 5 & 4114 & Oocyte meiosis & $1.46 \mathrm{E}-03$ & PTTG2, CCNB1, BUB1, RPS6KA3, CDK1 \\
\hline 2 & 740 & Riboflavin metabolism & $2.93 \mathrm{E}-03$ & ENPP1, ACP6 \\
\hline 4 & 4914 & Progesterone-mediated oocyte maturation & $4.03 \mathrm{E}-03$ & $C C N B 1, B U B 1, R P S 6 K A 3, C D K 1$ \\
\hline 4 & 5322 & Systemic lupus erythematosus & 4.37E-03 & HIST2H2AC, HIST1H2AJ, H2AFJ, SNRPDI \\
\hline 2 & 603 & Glycosphingolipid biosynthesis -globo series & $4.78 \mathrm{E}-03$ & $N A G A, B 3 G A L N T 1$ \\
\hline 2 & 900 & Terpenoid backbone biosynthesis & $5.49 \mathrm{E}-03$ & ACAT2, IDII \\
\hline 3 & 983 & Drug metabolism - other enzymes & $6.62 \mathrm{E}-03$ & IMPDH2, GMPS, TK1 \\
\hline 3 & 4150 & mTOR signaling pathway & $6.99 \mathrm{E}-03$ & EIF4B, RPS6, RPS6KA3 \\
\hline
\end{tabular}


the Pol II gene in $m i R-26 a-1, m i R-26 a-2$ and $m i R-26 b$ and MYC negatively regulates expression of these miRNAs (23). Thus, overexpression of MYC can modulate the expression of tumor-suppressive miRNAs in PCa cells.

Our present data showed that both $m i R-26 a$ and $m i R-26 b$ were significantly reduced in PCa clinical specimens and that restoration of these miRNAs inhibited cancer invasion, providing insights into the functional roles of $m i R-26 a$ and $m i R-26 b$ as tumor suppressors in PCa cells. Downregulation and tumor-suppressive roles of $m i R-26 a$ or $m i R-26 b$ have been reported in several types of cancers, such as bladder, breast cancer, hepatocellular carcinoma and oral cancer (19,24-26). Recently, we showed that loss of tumor-suppressive $m i R-26 a$ and $m i R-26 b$ enhanced cancer cell migration and invasion in oral squamous cell carcinoma through direct regulation of TMEM184B. Moreover, silencing of TMEM184B inhibited cancer cell migration and invasion and regulated actin cytoskeleton pathway-related genes.

In prostate cancer, several studies reported that $m i R-26 a$ and $m i R-26 b$ were downregulated in cancer tissues and that they functioned as tumor suppressors that targeted several oncogenic genes. Enhancer of zeste homolog 2 (EZH2) is a histone-lysine $\mathrm{N}$-methyltransferase enzyme and component of the polycomb repressive complex $2(27,28)$. Overexpression of EZH2 is observed in several cancers, including PCa (29-31). Interestingly, restoration of $m i R-26 a$ and $m i R-26 b$ reduced EZH2 expression and suppressed proliferation of $\mathrm{PCa}$ cells (23). A recent study showed that $m i R-26 a$ directly targeted LIN28B and ZCCHCII (32). Moreover, the present study demonstrated that $Z C C H C 11$ was overexpressed in human cancers and that $Z C C H C 11$ promoted cancer cell growth and metastasis (32). It is well known that LIN28B, an RNA-binding protein, has suppressive roles in let-7-family biogenesis. Moreover, the LIN28/let-7 regulatory circuit widely influences development and human cancers (33-36). Previous studies showed that downregulation of the let-7family was frequently observed in PCa tissues and they acted as tumor-suppressive miRNAs in PCa cells $(37,38)$. Therefore, it appears that restoration of $m i R-26 a$ enhanced let-7 biogenesis through its targeting of LIN28B as a let-7 suppressor, and consequently, inhibited cancer cell proliferation and metastasis (32).

Identification of miRNA regulatory networks in cancer cells might contribute to the elucidation of novel molecular mechanisms of human oncogenesis and metastasis. In the present study, we performed a combination of genome-wide gene expression analysis and in silico analysis to identify $m i R-26 a$ and $m i R-26 b$ targets in PCa cells. Recent miRNA studies in our laboratory have utilized this strategy to successfully identify novel molecular targets and pathways regulated by tumor-suppressive miRNAs in several cancers, including PCa (12-15). A total of 10 putative candidate genes regulated by $m i R-26 a / b$ are documented in this study. Among them, we focused on LARP1, an RNA-binding protein, because the functional roles of the gene in the development of PCa have not been elucidated. Our data confirmed overexpression of $L A R P I$ in clinical specimens of PCa and silencing $L A R P 1$ inhibited PCa cell migration. These data strongly suggested that $L A R P I$ has an oncogenic function in PCa cells. Overexpression of $L A R P 1$ was reported in other types of cancers, including hepatocellular carcinoma, cervical cancer and non-small cell lung cancer, and expression of the gene has correlated with clinical outcomes $(39,40)$.

Recent studies showed that $L A R P 1$ plays a critical role in the stabilization and translation of 5'-terminal oligopyrimidine tract (TOP) mRNAs, such as ribosomal proteins and elongation factors by interacting with their 5'- and 3'-untranslated regions (41-43). Moreover, recent studies indicated that LARP1 is phosphorylated by mTOR and is a key regulator of mTORC1 signaling $(40,44)$. We analyzed genes downstream of $L A R P 1$ by using si-LARPI transfectants. The data showed that several genes were involved in 'ribosome', 'RNA transport' and 'mTOR signaling pathways' These findings suggest that $L A R P 1$ is deeply involved in cancer progression and development through stabilization and regulation of TOP mRNAs in mTOR pathways.

In conclusion, downregulation of $m i R-26 a$ and $m i R-26 b$ was validated in PCa clinical specimens and these miRNAs were shown to function as tumor suppressors in PCa. To the best of our knowledge, this is the first report demonstrating that tumor-suppressive $m i R-26 a / b$ directly targeted LARP1 as an RNA-binding protein in PCa cells. Moreover, LARP1 was upregulated in PCa clinical specimens and contributed to cancer cell invasion, indicating that it functioned as an oncogene. The identification of novel molecular pathways and targets regulated by $m i R-26 a / b$ may lead to a better understanding of PCa oncogenesis and metastasis.

\section{Acknowledgements}

We are indebted to Dr Masafumi Kurosumi at Saitama Cancer Center for helpful insight and critical suggestion of pathological data. This study was supported by the KAKENHI (C), 24592590,(C), 15K10801,(B) 25293333 and Futaba Electronics Memorial Foundation.

\section{References}

1. Siegel RL, Miller KD and Jemal A: Cancer statistics, 2015. CA Cancer J Clin 65: 5-29, 2015.

2. Chi KN, Bjartell A, Dearnaley D, Saad F, Schröder FH, Sternberg C, Tombal B and Visakorpi T: Castration-resistant prostate cancer: From new pathophysiology to new treatment targets. Eur Urol 56: 594-605, 2009.

3. Sturge J, Caley MP and Waxman J: Bone metastasis in prostate cancer: Emerging therapeutic strategies. Nat Rev Clin Oncol 8: 357-368, 2011.

4. Carthew RW and Sontheimer EJ: Origins and Mechanisms of miRNAs and siRNAs. Cell 136: 642-655, 2009.

5. Bartel DP: MicroRNAs: Genomics, biogenesis, mechanism, and function. Cell 116: 281-297, 2004.

6. Filipowicz W, Bhattacharyya SN and Sonenberg N: Mechanisms of post-transcriptional regulation by microRNAs: Are the answers in sight? Nat Rev Genet 9: 102-114, 2008.

7. Hobert O: Gene regulation by transcription factors and microRNAs. Science 319: 1785-1786, 2008.

8. Friedman RC, Farh KK, Burge CB and Bartel DP: Most mammalian mRNAs are conserved targets of microRNAs. Genome Res 19: 92-105, 2009.

9. Iorio MV and Croce CM: MicroRNAs in cancer: Small molecules with a huge impact. J Clin Oncol 27: 5848-5856, 2009.

10. Kojima S, Chiyomaru T, Kawakami K, Yoshino H, Enokida H, Nohata N, Fuse M, Ichikawa T, Naya Y, Nakagawa M, et al: Tumour suppressors miR-1 and miR-133a target the oncogenic function of purine nucleoside phosphorylase (PNP) in prostate cancer. Br J Cancer 106: 405-413, 2012. 
11. Kojima S, Enokida H, Yoshino H, Itesako T, Chiyomaru T, Kinoshita T, Fuse M, Nishikawa R, Goto Y, Naya Y, et al: The tumor-suppressive microRNA-143/145 cluster inhibits cell migration and invasion by targeting GOLM1 in prostate cancer. J Hum Genet 59: 78-87, 2014.

12. Nishikawa R, Goto Y, Sakamoto S, Chiyomaru T, Enokida H, Kojima S, Kinoshita T, Yamamoto N, Nakagawa M, Naya Y, et al: Tumor-suppressive microRNA-218 inhibits cancer cell migration and invasion via targeting of LASP1 in prostate cancer. Cancer Sci 105: 802-811, 2014

13. Nishikawa R, Goto Y, Kojima S, Enokida H, Chiyomaru T, Kinoshita T, Sakamoto S, Fuse M, Nakagawa M, Naya Y, et al: Tumor-suppressive microRNA-29s inhibit cancer cell migration and invasion via targeting LAMC1 in prostate cancer. Int J Oncol 45: 401-410, 2014

14. Goto Y, Nishikawa R, Kojima S, Chiyomaru T, Enokida H, Inoguchi S, Kinoshita T, Fuse M, Sakamoto S, Nakagawa M, et al: Tumour-suppressive microRNA-224 inhibits cancer cell migration and invasion via targeting oncogenic TPD52 in prostate cancer. FEBS Lett 588: 1973-1982, 2014.

15. Goto Y, Kojima S, Nishikawa R, Enokida H, Chiyomaru T, Kinoshita T, Nakagawa M, Naya Y, Ichikawa T and Seki N: The microRNA-23b/27b/24-1 cluster is a disease progression marker and tumor suppressor in prostate cancer. Oncotarget 5 : 7748-7759, 2014.

16. Goto Y, Kurozumi A, Enokida H, Ichikawa T and Seki N Functional significance of aberrantly expressed microRNAs in prostate cancer. Int J Urol 22: 242-252, 2015.

17. Nelson KM and Weiss GJ: MicroRNAs and cancer: Past, present, and potential future. Mol Cancer Ther 7: 3655-3660, 2008.

18. Kikkawa N, Hanazawa T, Fujimura L, Nohata N, Suzuki H, Chazono H, Sakurai D, Horiguchi S, Okamoto Y and Seki N: miR-489 is a tumour-suppressive miRNA target PTPN11 in hypopharyngeal squamous cell carcinoma (HSCC). Br J Cancer 103: 877-884, 2010

19. Fukumoto I, Hanazawa T, Kinoshita T, Kikkawa N, Koshizuka K, Goto Y, Nishikawa R, Chiyomaru T, Enokida H, Nakagawa M et al: MicroRNA expression signature of oral squamous cell carcinoma: Functional role of microRNA-26a/b in the modulation of novel cancer pathways. Br J Cancer 112: 891-900, 2015.

20. Baylin SB, Esteller M, Rountree MR, Bachman KE, Schuebel K and Herman JG: Aberrant patterns of DNA methylation, chromatin formation and gene expression in cancer. Hum Mol Genet 10: 687-692, 2001.

21. Sandhu R, Rivenbark AG and Coleman WB: Loss of post-transcriptional regulation of DNMT3b by microRNAs: A possible molecular mechanism for the hypermethylation defect observed in a subset of breast cancer cell lines. Int J Oncol 41: 721-732, 2012.

22. Börno ST, Fischer A, Kerick M, Fälth M, Laible M, Brase JC, Kuner R, Dahl A, Grimm C, Sayanjali B, et al: Genome-wide DNA methylation events in TMPRSS2-ERG fusion-negative prostate cancers implicate an EZH2-dependent mechanism with miR-26a hypermethylation. Cancer Discov 2: 1024-1035, 2012.

23. Koh CM, Iwata T, Zheng Q, Bethel C, Yegnasubramanian S and De Marzo AM: Myc enforces overexpression of EZH2 in early prostatic neoplasia via transcriptional and post-transcriptional mechanisms. Oncotarget 2: 669-683, 2011.

24. Lin Y, Chen H, Hu Z, Mao Y, Xu X, Zhu Y, Xu X, Wu J, Li S, Mao Q, et al: miR-26a inhibits proliferation and motility in bladder cancer by targeting HMGA1. FEBS Lett 587: 2467-2473, 2013.

25. Zhang B, Liu XX, He JR, Zhou CX, Guo M, He M, Li MF, Chen GQ and Zhao Q: Pathologically decreased miR-26a antagonizes apoptosis and facilitates carcinogenesis by targeting MTDH and EZH2 in breast cancer. Carcinogenesis 32: 2-9, 2011.

26. Zhu Y, Lu Y, Zhang Q, Liu JJ, Li TJ, Yang JR, Zeng C and Zhuang SM: MicroRNA-26a/b and their host genes cooperate to inhibit the G1/S transition by activating the $\mathrm{pRb}$ protein. Nucleic Acids Res 40: 4615-4625, 2012.
27. Simon JA and Lange CA: Roles of the EZH2 histone methyltransferase in cancer epigenetics. Mutat Res 647: 21-29, 2008

28. Sparmann A and van Lohuizen M: Polycomb silencers control cell fate, development and cancer. Nat Rev Cancer 6: 846-856, 2006.

29. Raman JD, Mongan NP, Tickoo SK, Boorjian SA, Scherr DS and Gudas LJ: Increased expression of the polycomb group gene, EZH2, in transitional cell carcinoma of the bladder. Clin Cancer Res 11: 8570-8576, 2005

30. Kleer CG, Cao Q, Varambally S, Shen R, Ota I, Tomlins SA, Ghosh D, Sewalt RG, Otte AP, Hayes DF, et al: EZH2 is a marker of aggressive breast cancer and promotes neoplastic transformation of breast epithelial cells. Proc Natl Acad Sci USA 100: 11606-11611, 2003.

31. Varambally S, Dhanasekaran SM, Zhou M, Barrette TR, KumarSinha C, Sanda MG, Ghosh D, Pienta KJ, Sewalt RG, Otte AP, et al: The polycomb group protein EZH2 is involved in progression of prostate cancer. Nature 419: 624-629, 2002

32. Fu X, Meng Z, Liang W, Tian Y, Wang X, Han W, Lou G, Wang X, Lou F, Yen Y, et al: miR-26a enhances miRNA biogenesis by targeting Lin28B and Zcchc11 to suppress tumor growth and metastasis. Oncogene 33: 4296-4306, 2014.

33. Heo I, Joo C, Cho J, Ha M, Han J and Kim VN: Lin28 mediates the terminal uridylation of let-7 precursor MicroRNA. Mol Cell 32: $276-284,2008$.

34. Viswanathan SR, Daley GQ and Gregory RI: Selective blockade of microRNA processing by Lin28. Science 320: 97-100, 2008.

35. Hagan JP, Piskounova E and Gregory RI: Lin 28 recruits the TUTase Zcchc11 to inhibit let-7 maturation in mouse embryonic stem cells. Nat Struct Mol Biol 16: 1021-1025, 2009.

36. Piskounova E, Polytarchou C, Thornton JE, LaPierre RJ, Pothoulakis C, Hagan JP, Iliopoulos D and Gregory RI: Lin28A and Lin28B inhibit let-7 microRNA biogenesis by distinct mechanisms. Cell 147: 1066-1079, 2011

37. Liu C, Kelnar K, Vlassov AV, Brown D, Wang J and Tang DG: Distinct microRNA expression profiles in prostate cancer stem/ progenitor cells and tumor-suppressive functions of let-7. Cancer Res 72: 3393-3404, 2012

38. Nadiminty N, Tummala R, Lou W, Zhu Y, Shi XB, Zou JX, Chen H, Zhang J, Chen X, Luo J, et al: MicroRNA let-7c is downregulated in prostate cancer and suppresses prostate cancer growth. PLoS One 7: e32832, 2012.

39. Xie C, Huang L, Xie S, Xie D, Zhang G, Wang P, Peng L and Gao Z: LARP1 predict the prognosis for early-stage and AFP-normal hepatocellular carcinoma. J Transl Med 11: 272, 2013.

40. Mura M, Hopkins TG, Michael T, Abd-Latip N, Weir J, Aboagye E, Mauri F, Jameson C, Sturge J, Gabra H, et al: LARP1 post-transcriptionally regulates mTOR and contributes to cancer progression. Oncogene: Dec 22, 2014. doi.org/10.1038/ onc.2014.428 (Epub ahead of print).

41. Tcherkezian J, Cargnello M, Romeo Y, Huttlin EL, Lavoie G, Gygi SP and Roux PP: Proteomic analysis of cap-dependent translation identifies LARP1 as a key regulator of 5'TOP mRNA translation. Genes Dev 28: 357-371, 2014

42. Meyuhas $\mathrm{O}$ and Kahan T: The race to decipher the top secrets of TOP mRNAs. Biochim Biophys Acta: Sep 16, 2014. doi: 10.1016/j.bbagrm.2014.08.015 (Epub ahead of print).

43. Aoki K, Adachi S, Homoto M, Kusano H, Koike K and Natsume T: LARP1 specifically recognizes the 3 ' terminus of poly(A) mRNA. FEBS Lett 587: 2173-2178, 2013.

44. Andersen JN, Sathyanarayanan S, Di Bacco A, Chi A, Zhang T, Chen AH, Dolinski B, Kraus M, Roberts B, Arthur W, et al: Pathway-based identification of biomarkers for targeted therapeutics: Personalized oncology with PI3K pathway inhibitors. Sci Transl Med 2: 43ra55, 2010. 